\title{
Ecological drivers of testate amoeba diversity in tropical water bodies of central Mexico
}

\author{
Itzel SIGALA REGALADO,${ }^{1 *}$ Socorro LOZANO GARCÍA,${ }^{2}$ Liseth PÉREZ ALVARADO,${ }^{2}$ Margarita CABALLERO, ${ }^{3}$ \\ Alfonso LUGO VÁZQUEZ ${ }^{4}$
}

${ }^{1}$ Posgrado de Ciencias Biológicas, Instituto de Geología, Universidad Nacional Autónoma de México, Ciudad Universitaria, 04510 Ciudad de México; ${ }^{2}$ Instituto de Geología, Universidad Nacional Autónoma de México, Ciudad Universitaria, 04510, Ciudad de México; ${ }^{3}$ Instituto de Geofísica, Universidad Nacional Autónoma de México, Ciudad Universitaria, 04510 Ciudad de México; ${ }^{4}$ Proyecto de Investigación en Limnología Tropical, Unidad de Investigación Interdisciplinaria para las Ciencias de la Salud y Educación, Facultad de Estudios Superiores Iztacala, Universidad Nacional Autónoma de México, Av. de los Barrios No.1, Los Reyes Iztacala, Tlanepantla 54090, Estado de México, México

*Corresponding author: itzelsr@yahoo.com.mx

\begin{abstract}
Testate amoebae are unicellular organisms characterized by a shell-like test. Due to their potential use as bioindicators (and paleoindicators), these organisms have been increasingly studied in the last decade, particularly in temperate latitudes. This study's objective was two-fold: to identify the testate amoeba communities sampled from 29 water bodies in Mexico and to determine if their presence and distribution also made them suitable bioindicators for tropical latitudes. A total of 40 taxa were recorded within 12 genera, and six significant variables -oxygen, $\mathrm{pH}$, depth, temperature, conductivity, and total alkalinity - that explained testate amoeba distribution within and among the water bodies were identified through a canonical correspondence analysis. The Q-mode clusters rendered five assemblages, each named after their respective dominant species: 1) Centropyxis aculeata strain "aculeata" assemblage, 2) Difflugia oblonga strain "bryophila" assemblage, 3) diverse assemblage, 4) Cucurbitella tricuspis assemblage, and 5) Difflugia protaeiformis strain "acuminata" assemblage. We found that Cucurbitella tricuspis and the Difflugia protaeiformis strain "acuminata" have similar ecological preferences to those reported previously for temperate lakes, with the former identified as an indicator of eutrophic environments and the latter as an indicator of low oxygen levels. On the other hand, Centropyxis aculeata strain "aculeata" and Arcella vulgaris seem to indicate adverse conditions, but the source of this environmental stress apparently differs from that reported in temperate latitudes. Although this stress source could not be identified in all cases, our study nonetheless demonstrates that testate amoebae in the water bodies of central Mexico could reveal the presence of environmental stress.
\end{abstract}

Key words: Amoebozoa; bioindicators; ecology; environmental stress; proxies; Rhizopoda; Thecamoebians.

Received: August 2017. Accepted: May 2018.

\section{INTRODUCTION}

Testate amoebae are a polyphyletic group of singlecelled ameboid protists in which the cytoplasm is enclosed within an external shell or discrete test. Some species have an autogenous test that can be proteinaceous, siliceous or, rarely, calcareous, whereas other species feature xenogenous tests formed by agglutinated organic or mineral particles captured from their surrounding environment (Armynot du Châtelet et al., 2015).

In the last decade, interest in testate amoebae as bioindicators and paleoenvironmental indicators has been growing (Meyer et al., 2012; Qin et al., 2013; Swindles et al., 2015). One characteristic that makes this group of organisms very useful is the high diversity of their test morphologies, which enables their identification down to the species level (Escobar et al.,
2008). Good preservation of the tests is common in sediment material, since they can tolerate even low $\mathrm{pH}$ levels that tend to dissolve other taxonomic groups, such as ostracods and gastropods (Kumar and Patterson, 2000). Testate amoebae can also serve as reliable bioindicators of environmental changes, especially in Quaternary studies, because their communities are capable of reorganizing themselves quickly in response to environmental changes (Payne, 2013).

Limnological studies have documented the responses of testate amoebae to temperature (Mattheeussen et al., 2005), seasonality (Farooqui et al., 2012), pH and oxygen concentration (Patterson and Kumar, 2000; Escobar et al., 2008), heavy metal content (Asioli et al., 1996; Patterson et al., 1996), phosphorus (Roe et al., 2010) and salt contamination (Roe and Patterson, 2014). But most of this research has been carried out in lakes in temperate regions (Patterson and Kumar, 2000; Roe et al., 2010; Fernández et al., 2012; Roe and Patterson, 2014) with only few 
studies available for tropical lakes (Dalby et al., 2000; Escobar et al., 2008, Maia-Barbosa et al., 2008; de Oliveira and Hardoim, 2010). In some tropical regions, the abundance of testate amoebae is actually lower than that of temperate lakes, making ecological studies difficult (Dalby et al., 2000), though several species, such as Arcella vulgaris and Centropyxis aculeata, apparently have similar ecological responses to stressed environments (high levels of heavy metal contamination or brackish conditions) as those in temperate regions to (Escobar et al., 2008; Farooqui et al., 2012).

The Trans-Mexican Volcanic Belt (TMVB) is the largest Neogenic volcanic arch in North America, crossing central Mexico from east to west. Its topographical heterogeneity has favored the formation of several water bodies that vary in origin, area, depth, trophic state and salinity along its extension (Davies et al., 2002; Armienta et al., 2008; Sigala et al., 2017). These conditions make these water bodies ideal for ecological and paleoecological studies because their sediments likely retain a detailed record of climate and environmental changes, both natural and anthropogenic. Some of these water bodies have already been affected by climate change (Gomez-Tagle et al., 2002; Caballero et al., 2015), which is worrying, since under these scenarios, we still lack baseline information about the microfauna inhabiting them. Therefore, up-to-date limnological investigation of these water bodies and the species dwelling there are required. This study had two aims: i) to identify the testate amoeba communities occurring in 29 water bodies in central Mexico and ii) to investigate the main environmental variables that define the presence, distribution and abundance of testate amoebae in tropical latitudes.

\section{METHODS}

\section{Study area}

The TMVB, a region formed as a consequence of intense volcanic activity during the Tertiary, spans from the Pacific, across central Mexico, up to the Gulf of Mexico. It covers over $160,000 \mathrm{~km}^{2}$, ranging in width from 90 to $230 \mathrm{~km}$. Because of its uneven topography, there are many water bodies along the TMVB, varying widely in altitude and local weather conditions (Ferrari et al., 2012; Sigala et al., 2017). Several human populations have settled near these water bodies, using them for different purposes, such as sources of drinking water, or for economic and even recreational activities. From a scientific standpoint, however, these water bodies have not yet received the attention they deserve, as most of them remain uncharacterized, and the flora and fauna supported by them is also largely unknown.
For this study, 29 water bodies along the TMVB were chosen (Fig. 1) that covered different environmental gradients; these water bodies were recently described by Sigala et al. (2017). Seventeen of these water bodies are volcanic in origin, eight are dam reservoirs and four are tectonic; their depths range from 0.5 to $65 \mathrm{~m}$, with the volcanic lakes being the deepest. They are located between 737 and $4283 \mathrm{~m}$ asl and span a wide amplitude of climatic conditions, from dry and warm to high-altitude cold. Most of these water bodies contain fresh and alkaline waters. According to their annual maximum content of chlorophyll, these water bodies span all trophic categories: ultra-oligotrophic, oligotrophic, mesotrophic, eutrophic and hypertrophic (OECD, 1982).

\section{Sampling of the water bodies}

Two surface sediment samples were taken from each water bodies, from a littoral and a deep zone (the former only for small and shallow water bodies), in August 2010 (Lakes El Sol and La Luna) and between June and October 2011 (the rest of the water bodies). If the water depth was very shallow (i.e., $<1 \mathrm{~m}$ ), the sediment was collected directly with a spatula, and if deeper, with an Ekman dredge, taking care to remove only the top $(1 \mathrm{~cm})$ sediment layer. All samples were preserved with anhydrous ethanol and kept refrigerated until analyzed in the laboratory.

In the field, water depth (m) was measured using a portable depth sounder (Speedtech Instruments), while the water's temperature $\left({ }^{\circ} \mathrm{C}\right)$, oxygen concentration $\left(\mathrm{mg} \mathrm{L}^{-1}\right)$, $\mathrm{pH}$ and electric conductivity $\left(\mu \mathrm{Scm}^{-1}\right)$ were measured using a multiparametric probe (Hydrolab Quanta G). Major ions analyses were performed following standard procedures (APHA, 1995, 1998, 2005; Armienta et al., 2008). Total dissolved inorganic carbon $\left(\mu \mathrm{g} \mathrm{Cg}^{-1}\right)$ was measured with an AutoMate carbonate preparation device. Total phosphorus $\left(\mathrm{mg} \mathrm{L}^{-1}\right)$ and orthophosphate $\left(\mathrm{mg} \mathrm{L}^{-1}\right)$ were determined in a Thermo Scientific Genesys 20 Visible spectrophotometer. Silica $\left(\mathrm{mg} \mathrm{L}^{-1}\right)$ was colorimetrically determined by the molybdosilicate method. Nutrient concentrations were expressed as $\mathrm{mg} \mathrm{L}^{-1}$, merging $\left[\mathrm{N}^{-\mathrm{NH}_{4}}\right]$ $+\left[\mathrm{N}-\mathrm{NO}_{3}\right]+\left[\mathrm{N}^{-} \mathrm{NO}_{2}\right]$ to express total dissolved inorganic nitrogen $\left(\mathrm{mg} \mathrm{L}^{-1}\right)$.

Samples used for the chlorophyll $a$ determinations were filtered in the field with a Whatman $\mathrm{GF} / \mathrm{C}$ membrane, and the filters kept refrigerated and in darkness until their arrival in the laboratory. Extractions were made using methanol $(90 \%)$, concentrations were measured with a spectrophotometer (Thermo Scientific Genesys 20 Visible) and determined using Holden's equations (Meeks, 1974). Detailed information of the water bodies such as their location, sampling, field measurements, water chemistry and nutrients analysis are described in Sigala et al. (2017). 


\section{Laboratory analyses}

For the testate amoebae analysis, from each sample, 2 cc of wet sediment was sieved through a $53-\mu \mathrm{m}$ screen to retain tests of a size easily identifiable under a stereomicroscope. Each sieved sample was observed in a Petri dish at a magnification of $64 \mathrm{x}$ to $100 \mathrm{x}$ with a stereomicroscope (Zeiss STEMI 2000-C Schott SerieEasyLED). All the tests were then extracted with a fine paintbrush, counted and kept in Eppendorf tubes with anhydrous ethylic alcohol. Taxonomic keys were used for their identification: namely, Ogden and Hedley (1980), Kumar and Dalby (1998) and Lee et al. (2000). Lacustrine arcellacean species can display great ecophenotypically controlled morphological variability. It is an accepted practice that researchers working in lakes assign informal infra-subspecific 'strain' names for ecophenotypes, largely to avoid the possible description of unjustified new species (Patterson and Kumar, 2000). Although the
International Code of Zoological Nomenclature stipulates that infra-subspecific-level designations have no taxonomic status (ICZN, 1999), they are useful for distinguishing environmentally significant populations in lacustrine environments (Patterson et al., 2012).

\section{Statistical analyses}

Shannon diversity indices were calculated to obtain information about the relative health of the environment, according to Patterson and Kumar (2002). Unfavorable environments typically have faunas dominated by one or two taxa, so the Shannon diversity index values for them should be low (between 0.1 and 1.5). By contrast, in healthy environments (stress-free), the distribution of species is more balanced, so Shannon values between 2.5 and 3.5 should be expected.

To identify those environmental variables associated with the presence and abundance of testate amoebae, a

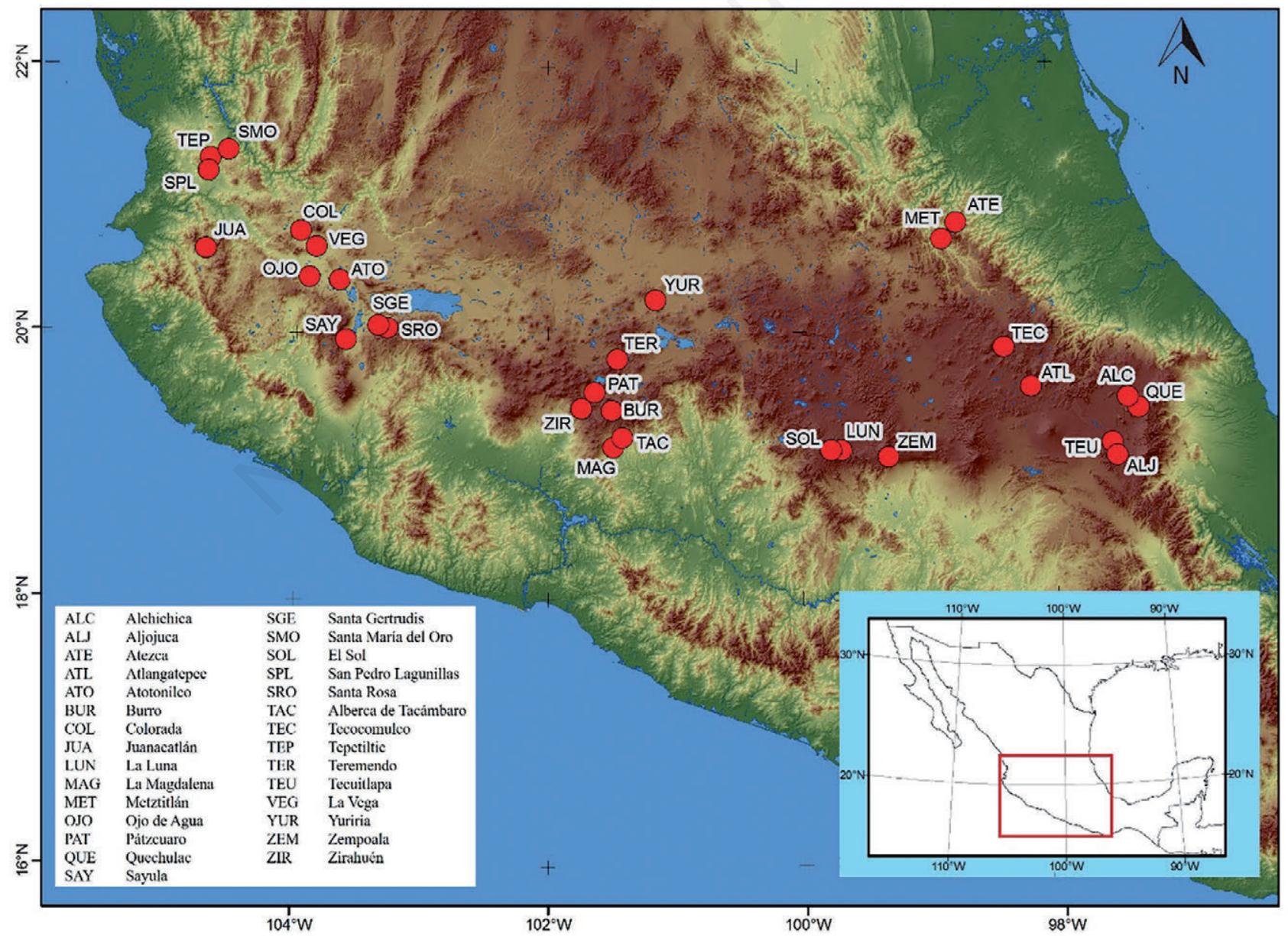

Fig. 1. Map showing the location of sampled lakes (red points), with a close up of the central region of Mexico, where the TransMexican Volcanic Belt is located. Differences in topographical relief are shown in colors. Modified from Sigala et al., 2017, Bol. Soc. Geol. Mex. 69:313-370. 
canonical correspondence analysis (CCA) was performed using all the species recorded. Analysis of variance (ANOVA) performed with 999 permutations was used to recognize the significant explanatory variables.

To establish which species were associated with each other in forming distinct assemblages, we obtained Q- and R-mode clusters (Roe and Patterson, 2014). For the Q mode, the Euclidean distance was used. The "complete" method was used for clustering. We used detrended correspondence analysis (DCA) to determine the water bodies association within the ecological space. The standard error associated with each taxon was calculated using:

$S x i=1.96 \sqrt{\frac{F i(1-F 1)}{N i}}$

where $F i$ is the relative fractional abundance of each taxon, and $\mathrm{Ni}$ is the total of all the species counts in that sample (Patterson et al., 2012). Only statistically significant species - those for whom the standard error was less than their fractional abundance in all the samples; Patterson and Fishbein (1989) - were included in the cluster and DCA analyses, and the samples with less than 50 individuals were eliminated (Payne and Mitchell, 2009).

\section{RESULTS}

\section{Species richness and spatial distributions}

A total of 40 testate amoebae taxa, consisting of 17 varieties and 23 species distributed in 12 genera, were identified in the 29 water bodies of central Mexico (Tab. 1). The relative abundance of all species in the water bodies is shown in Supplementary Tab. S1. Centropyxis aculeata strain "aculeata" was the taxon found in most water bodies $(\mathrm{n}=22)$, followed by Arcella discoides $(\mathrm{n}=17)$ and Cucurbitella tricuspis $(\mathrm{n}=14)$. Two species of Difflugia were found in 13 of the 29 water bodies (Difflugia protaeiformis strain "acuminata", Difflugia urceolata strain "elongata"). In contrast, some species were only recorded in a single lake and in low abundance: Arcella conica was only found in Burro, Centropyxis deflandrei in Alchichica, Centropyxis ecornis in Colorada, Cyphoderia ampulla in Santa María del Oro, Difflugia bicruris in Zirahuén, Lesquereusia spiralis in Alberca de Tacámbaro and Scutiglypha cabrolae in Tacámbaro. The only lake where Pseudodifflugia fulva was recorded was Aljojuca, but unlike the aforementioned species, this occurred at a relatively higher abundance, accounting for almost $13 \%$ of the testate amoeba community there. Complete descriptions and illustrations of these taxa are available in Sigala et al. (2016).

\section{Species diversity}

Eight water bodies showed the highest species richness and total abundance in the deep zone sediment sample; in six water bodies, the highest values were found in the littoral zone; in four water bodies, the highest species richness was found in the deep zone, but the littoral sample had higher abundances (Tab. 2). In one lake only, the littoral zone had a higher species richness, for which the deep zone displayed a higher total abundance. In most of the water bodies, species assemblages differed between the deep and littoral zone samples. In seven water bodies - Alchichica, La Magdalena, Pátzcuaro, Quechulac, Sayula, San Pedro Lagunillas and Teremendo - there were no species shared between both zones and only at Lake Colorada did both littoral and deeper samples share several species (nine species found in the littoral, eight of which were also observed in the deeper sample). The deep sample from Lake Atlangatepec had the highest richness with 15 species. Both samples from lake Atotonilco and those from three other sites (littoral samples from Quechulac and Teremendo and the deep sample from Sayula) did not contain any testate amoebae, so they were excluded from our numerical analysis. The sample with the highest abundance, 1889 specimens, was recorded in the deep zone of Lake Ojo de Agua. The Shannon index was calculated for every zone sample; 23 of them had values below 1.5 and 15 (range: 1.5-2.3).

\section{Relationship between environmental variables and species}

To identify the environmental variables associated with the presence and abundance of the testate amoebae, a CCA was performed, which included all the recorded species and 20 environmental variables: water's depth (m), temperature $\left({ }^{\circ} \mathrm{C}\right)$, dissolved oxygen $\left(\mathrm{mg} \mathrm{L}^{-1}\right)$, electric conductivity $\left(\mu \mathrm{S} \mathrm{cm}^{-1}\right)$, total alkalinity $\left(\mathrm{mg} \mathrm{L}^{-1}\right), \mathrm{CO}_{3}{ }^{2-}$ (mg L $\left.{ }^{-1}\right), \mathrm{HCO}_{3}^{-}\left(\mathrm{mg} \mathrm{L}^{-1}\right), \mathrm{SO}_{4}{ }^{2-}\left(\mathrm{mg} \mathrm{L}^{-1}\right), \mathrm{Cl}^{-}\left(\mathrm{mg} \mathrm{L}^{-1}\right)$, $\mathrm{Na}^{+}\left(\mathrm{mg} \mathrm{L}^{-1}\right), \mathrm{K}^{+}\left(\mathrm{mg} \mathrm{L}^{-1}\right), \mathrm{Ca}^{2+}\left(\mathrm{mg} \mathrm{L}^{-1}\right), \mathrm{Mg}^{2+}\left(\mathrm{mg} \mathrm{L}^{-1}\right)$, total dissolved solids $\left(\mathrm{mg} \mathrm{L}^{-1}\right)$, dissolved inorganic carbon $(\mu \mathrm{gC} \mathrm{g}-1), \mathrm{SiO}_{2}\left(\mathrm{mg} \mathrm{L}^{-1}\right)$, dissolved inorganic nitrogen ( $\mathrm{mg} \mathrm{L}^{-1}$ ), total phosphorous ( $\mathrm{mg} \mathrm{L}^{-1}$ ), $\mathrm{P}-\mathrm{PO}_{4}\left(\mathrm{mg} \mathrm{L}^{-1}\right)$, and chlorophyll $a\left(\mathrm{mg} \mathrm{m}^{3-1}\right)$. The ANOVA test revealed six significant variables (Figs. 2 and 3): temperature $(\mathrm{P}<0.001)$, sample depth $(\mathrm{P}<0.002)$, dissolved oxygen $(\mathrm{P}<0.006)$, conductivity $(\mathrm{P}<0.008)$, total alkalinity $(\mathrm{P}<0.017)$ and $\mathrm{pH}(\mathrm{P}<0.023)$.

The CCA suggested that the first axis (eigenvalue $=0.7925$ ) was positively correlated with dissolved oxygen, and to a lesser extent, with $\mathrm{pH}$ and temperature, but negatively with sample's water depth. The second axis (eigenvalue $=0.6526$ ) correlated with conductivity and total alkalinity. Together, the two axes explained $39.9 \%$ of the total variance in the dataset.

To more easily identify the assemblages among sites and species, Q- and R-mode cluster analysis and DCA 
were performed. For the assemblage characterization, the R-mode analysis identified nine species: Centropyxis aculeata strain "aculeata", Cucurbitella tricuspis, Difflugia protaeiformis strain "acuminata", Difflugia oblonga strain "bryophila", Arcella vulgaris, Centropyxis constricta strain "spinosa", Arcella discoides, Difflugia protaeiformis strain "amphoralis", and Difflugia urceolata strain "elongata". In the Q-mode analysis, five testate amoeba assemblages were identified, each named after the dominant species present: 1) Centropyxis aculeata

Tab. 1. Taxa registered in central Mexican lakes.

\begin{tabular}{|c|c|c|c|}
\hline & Taxa & Code & Lakes* \\
\hline 1 & Arcella conica Deflandre, 1928 & Aco & 1 \\
\hline 2 & Arcella dentata Ehrenberg, 1830 & Ade & 4 \\
\hline 3 & Arcella discoides Ehrenberg, 1843 & Adi & 17 \\
\hline 4 & Arcella gibbosa Penard, 1890 & Agi & 2 \\
\hline 5 & Arcella megastoma Penard, 1902 & Ame & 5 \\
\hline 6 & Arcella vulgaris Ehrenberg, 1830 & Avu & 9 \\
\hline 7 & Argynnia triangulata Deflandre, 1936 & Atr & 2 \\
\hline 8 & Centropyxis aculeata Ehrenberg, 1832 strain "aculeata" & Caa & 22 \\
\hline 9 & Centropyxis aculeata Ehrenberg, 1832 strain "discoides" & $\mathrm{Cad}$ & 10 \\
\hline 10 & Centropyxis constricta Ehrenberg, 1843 strain "aerophila" & Cca & 9 \\
\hline 11 & Centropyxis constricta Ehrenberg, 1843 strain "constricta" & $\mathrm{Ccc}$ & 2 \\
\hline 12 & Centropyxis constricta Ehrenberg, 1843 strain "spinosa" & Ccs & 8 \\
\hline 13 & Centropyxis deflandrei Rampi, 1950 & Cde & 1 \\
\hline 14 & Centropyxis ecornis Ehrenberg, 1841 & $\mathrm{Cec}$ & 1 \\
\hline 15 & Cucurbitella tricuspis Carter, 1856 & $\mathrm{Ctr}$ & 14 \\
\hline 16 & Cyclopyxis kahli Deflandre, 1929 & Cka & 5 \\
\hline 17 & Cyphoderia ampulla Ehrenberg, 1840 & Cam & 1 \\
\hline 18 & Difflugia bidens Penard, 1902 & Dbi & 5 \\
\hline 19 & Difflugia distenda Gauthier-Lièvre and Thomas, 1958 & Ddi & 1 \\
\hline 20 & Difflugia fragosa Hempel, 1898 & Dfr & 2 \\
\hline 21 & Difflugia labiosa (Leidy, 1874) Penard, 1902 & Dla & 2 \\
\hline 22 & Difflugia oblonga Ehrenberg, 1832 strain "bryophila" & Dob & 3 \\
\hline 23 & Difflugia oblonga Ehrenberg, 1832 strain "glans" & Dog & 4 \\
\hline 24 & Difflugia oblonga Ehrenberg, 1832 strain "lanceolata" & Dla & 4 \\
\hline 25 & Difflugia oblonga Ehrenberg, 1832 strain "linearis" & Dli & 2 \\
\hline 26 & Difflugia oblonga Ehrenberg, 1832 strain "oblonga" & Doo & 11 \\
\hline 27 & Difflugia oblonga Ehrenberg, 1832 strain "spinosa" & Dos & 5 \\
\hline 28 & Difflugia oblonga Ehrenberg, 1832 strain "tenuis" & Dot & 7 \\
\hline 29 & Difflugia protaeiformis Lamarck, 1816 strain "acuminata" & Dpa & 13 \\
\hline 30 & Difflugia protaeiformis Lamarck, 1816 strain "amphoralis" & Dpm & 9 \\
\hline 31 & Difflugia protaeiformis Lamarck, 1816 strain "claviformis" & Dpc & 2 \\
\hline 32 & Difflugia urceolata Carter, 1864 strain "elongata" & Due & 13 \\
\hline 33 & Difflugia urceolata Carter, 1864 strain "urceolata" & Duu & 8 \\
\hline 34 & Euglypha acanthophora Ehrenberg, 1814 & Eac & 2 \\
\hline 35 & Lesquereusia modesta Rhumbler, 1895 & Lmo & 4 \\
\hline 36 & Lesquereusia spiralis Ehrenberg, 1840 & Lsp & 1 \\
\hline 37 & Mediolus corona (Wallich, 1864) & Mco & 12 \\
\hline 38 & Pentagonia maroccana Gauthier-Lièvre and Thomas, 1958 & Pma & 4 \\
\hline 39 & Pseudodifflugia fulva Archer, 1870 & Pfu & 1 \\
\hline 40 & Scutiglypha cabrolae Smet and Gibson, 2009 & Sca & 1 \\
\hline
\end{tabular}

* Number of lakes where the taxon was recorded. 
Tab. 2. Number of species, tests and diversity index in each sample.

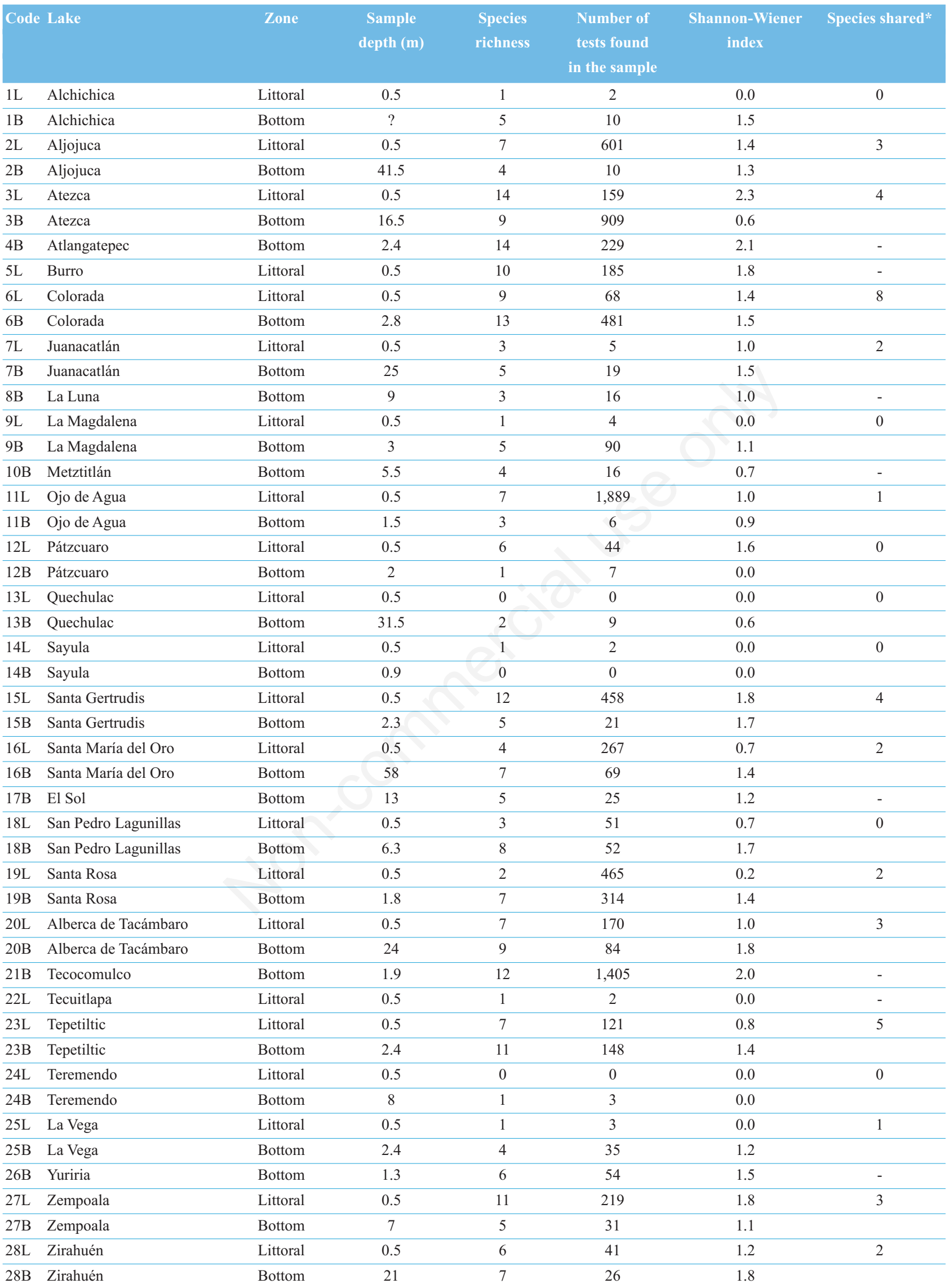

*Between littoral and bottom samples of the same lake. 
strain "aculeata" assemblage, 2) Difflugia oblonga strain "bryophila" assemblage, 3) Diverse assemblage, 4) Cucurbitella tricuspis assemblage and 5) Difflugia protaeiformis strain "acuminata" assemblage (Fig. 4).

\section{Centropyxis aculeata strain "aculeata" assemblage}

This group is dominated by Centropyxis aculeata strain "aculeata", which across all sites had a relative abundance of 30-87\%. Both Centropyxis constricta strain "spinosa" and Arcella discoides also occurred in this group, with relative abundances $20-35 \%$. All the samples belonging to this group corresponded to shallow water environments (i.e., $<3 \mathrm{~m}$ deep).

\section{Difflugia oblonga strain "bryophila" assemblage}

This group stands out from the rest, corresponding to the littoral zone sample from Lake Santa María del Oro (16 L), where the Difflugia oblonga strain "bryophila"

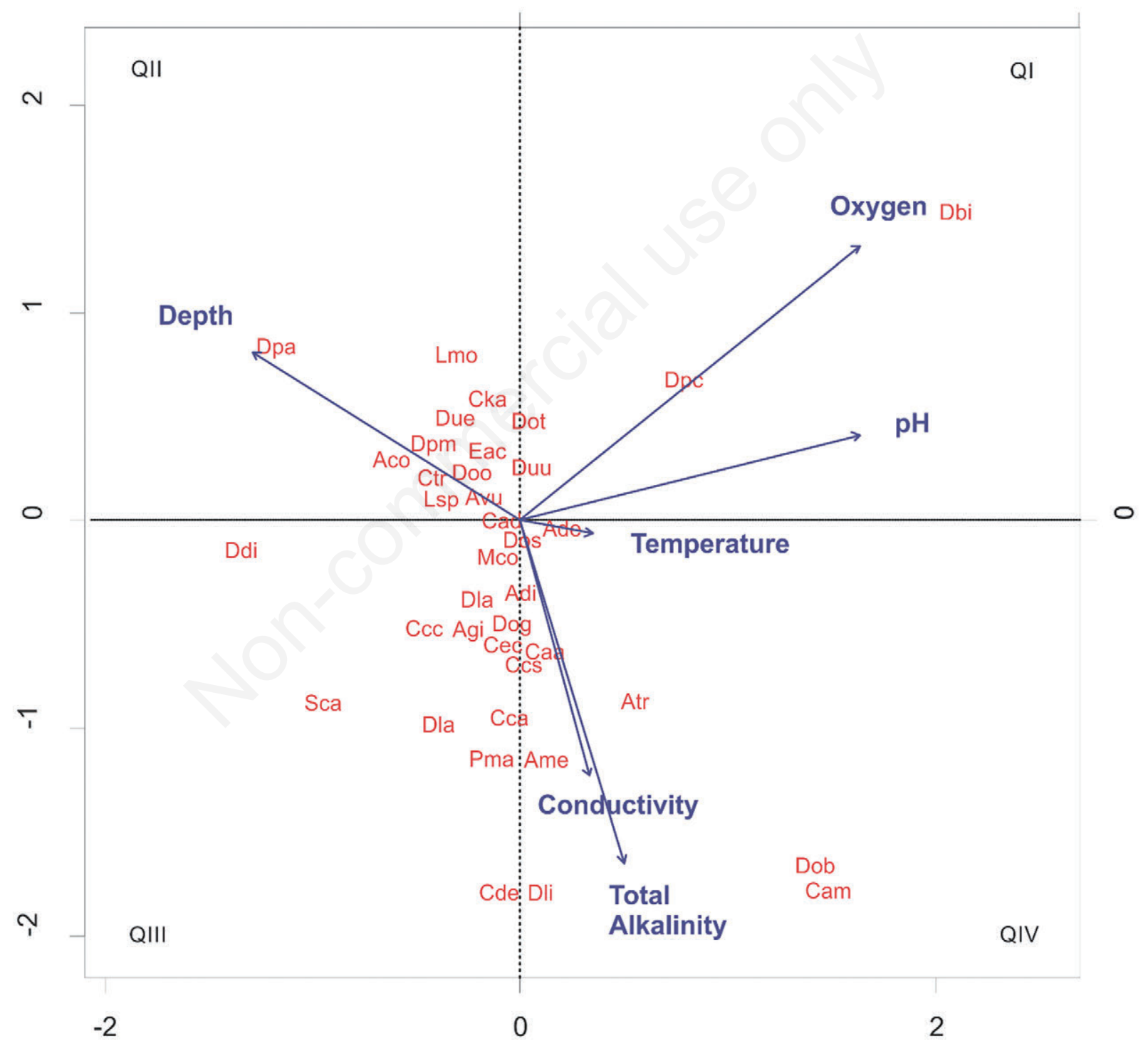

\section{CCA1}

Fig. 2. Canonical correspondence analysis (CCA) biplot showing only the testate amoebae species and the six variables that resulted in a significant ANOVA test. Axis 1 explained $21.9 \%$ of the variance and is related to oxygen, $\mathrm{pH}$, water depth, and water temperature. Axis 2 explained $18 \%$ of the variance and is related to conductivity and total alkalinity. Codes for the species are given in Tab. 1. 
was dominant (>70\%), and Centropyxis aculeata strain "aculeata" was also present. The CCA shows that this sample and these species are associated with high total alkalinity and conductivity levels (Figs. 2 and 3, QIV).

\section{Diverse assemblage}

This group is defined by seven species with variable abundances, but only Cucurbitella tricuspis was present at all the sites, ranging in abundance from $13 \%$ to $35 \%$. The species with the highest abundance is Arcella vulgaris, present in two samples (5L and $26 \mathrm{~B}$ at $52 \%$ and $37 \%$, respectively). The Centropyxis aculeata strain "aculeata" was found in low abundance (8-33\%) across all the samples, except for 5L. Arcella discoides, Difflugia urceolata strain "elongata", and both Difflugia protaeiformis strain "amphoralis" and strain "acuminata", were also all present with low abundances $(<30 \%)$. This group included samples from the littoral and deeper zones, but the lakes these came from were shallow, with the deepest being $4 \mathrm{~B}$ at $2.4 \mathrm{~m}$.

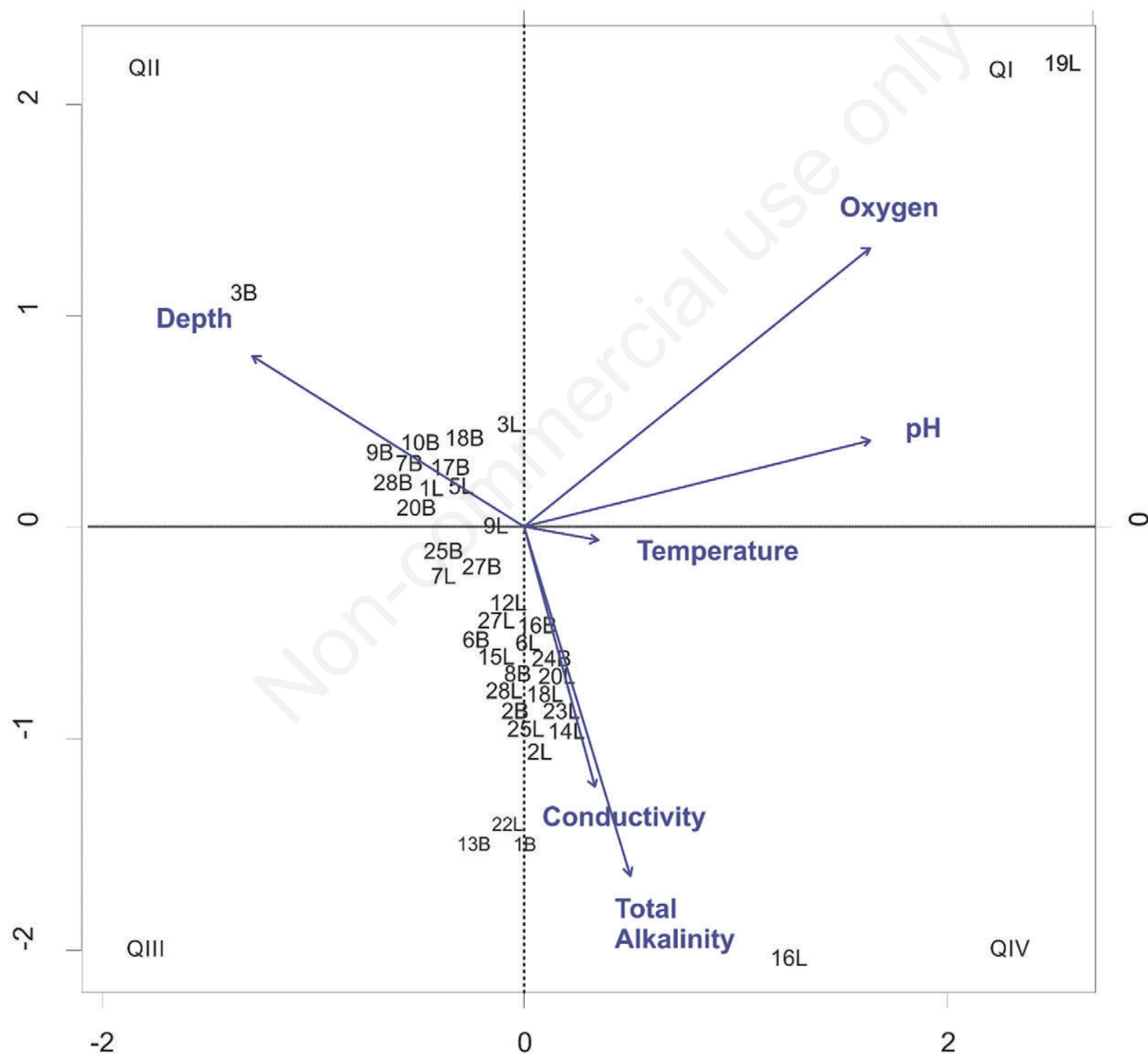

CCA1

Fig. 3. Canonical correspondence analysis (CCA) biplot showing only the lake sites and six variables that resulted in a significant ANOVA test. Axis 1 explained $21.9 \%$ of the variance and is related to oxygen, $\mathrm{pH}$, water depth, and water temperature. Axis 2 explained $18 \%$ of the variance and is related to conductivity and total alkalinity. Codes for the lakes are given in Tab. 2. 


\section{Cucurbitella tricuspis assemblage}

The dominant species in this group is Cucurbitella tricuspis; it was recorded at all sites with relative abundances ranging from $60 \%$ to $72 \%$. The three sites corresponded to deep zone samples, although these water bodies were rather shallow, with depths from 1.8 to $3 \mathrm{~m}$.

\section{Difflugia protaeiformis strain "acuminata" assemblage}

This group is defined by a single site, which stood out from the rest because it was strongly dominated $(85 \%)$ by the Difflugia protaeiformis strain "acuminata". This sample from Lake Atezca (3B) was collected at a water depth of $16.5 \mathrm{~m}$. Both the site and the species are associated in the CCA with greater water depth values.

Tab. 3. Environmental variables of sampled sites.

\begin{tabular}{|c|c|c|c|c|c|c|}
\hline Code & $\begin{array}{c}\text { Temperature } \\
\left({ }^{\circ} \mathrm{C}\right)\end{array}$ & $\begin{array}{l}\text { Sample } \\
\text { depth } \\
\text { (m) }\end{array}$ & $\begin{array}{l}\text { Dissolved } \\
\text { oxygen } \\
(\mathrm{mg} / \mathrm{L})\end{array}$ & $\begin{array}{c}\text { Electric } \\
\text { conductivity } \\
(\mu \mathrm{S} / \mathrm{cm})\end{array}$ & $\begin{array}{l}\text { Total } \\
\text { alkalinity } \\
\text { (mg/L) }\end{array}$ & pH \\
\hline $1 \mathrm{~L}$ & - & 0.5 & - & - & 2,193 & - \\
\hline $1 \mathrm{~B}$ & - & - & - & 14,730 & 2,172 & 10.2 \\
\hline $2 \mathrm{~L}$ & - & 0.5 & - & - & 651 & - \\
\hline $2 \mathrm{~B}$ & 15.3 & 41.5 & 0.2 & 1,147 & 635 & 9.5 \\
\hline $3 \mathrm{~L}$ & 27.2 & 0.5 & 7.8 & 97 & 52 & 9.9 \\
\hline $3 \mathrm{~B}$ & - & 16.5 & - & 174 & 75 & 7.7 \\
\hline $5 \mathrm{~L}$ & 19.7 & 0.5 & 5.3 & 27 & 16 & 6.9 \\
\hline $6 \mathrm{~L}$ & 29 & 0.5 & 9.1 & 615 & 239 & 8.1 \\
\hline $6 \mathrm{~B}$ & 24.2 & 2.8 & 4.4 & 618 & 236 & 7.4 \\
\hline $7 \mathrm{~L}$ & 21.4 & 0.5 & 6.8 & 123 & 64 & 9.3 \\
\hline $7 \mathrm{~B}$ & 13.6 & 25 & 0.18 & 178 & 94 & 7.7 \\
\hline $8 \mathrm{~B}$ & 7.5 & 9 & 5.9 & 9 & 4.2 & 6.4 \\
\hline $9 \mathrm{~L}$ & - & 0.5 & - & - & 58 & - \\
\hline 9B & 24.2 & 3 & 0.4 & 129 & 58 & 8.3 \\
\hline 10B & 23.9 & 5.5 & 5 & 508 & 378 & 8.8 \\
\hline $12 \mathrm{~L}$ & - & 0.5 & - & 830 & 427 & 8.3 \\
\hline $13 \mathrm{~B}$ & 41.2 & 31.5 & 0.3 & 781 & 338 & 9.2 \\
\hline $14 \mathrm{~L}$ & 22.8 & 0.5 & 5.2 & 3,890 & 1,179 & 9.4 \\
\hline $15 \mathrm{~L}$ & 23 & 0.5 & 3.9 & 156 & 80 & 7.6 \\
\hline $16 \mathrm{~L}$ & - & 0.5 & - & 1,347 & 439 & 8.6 \\
\hline 16B & 21.8 & 58 & 0.08 & 1,430 & 480 & 7.8 \\
\hline 17B & 8.7 & 13 & 6.3 & 87 & 36 & 7 \\
\hline $18 \mathrm{~L}$ & 30.2 & 0.5 & 9.1 & 273 & 125 & 8 \\
\hline $18 \mathrm{~B}$ & - & 6.3 & - & 269 & 121 & 7.9 \\
\hline $19 \mathrm{~L}$ & 22.8 & 0.5 & 9.2 & 224 & 120 & 9.2 \\
\hline $20 \mathrm{~L}$ & - & 0.5 & - & - & 128 & - \\
\hline 20B & 16.72 & 24 & 0.09 & 208 & 122 & 7.3 \\
\hline $22 \mathrm{~L}$ & 26.2 & 0.5 & 5.7 & 3,710 & 2,047 & 10.3 \\
\hline $23 \mathrm{~L}$ & - & 0.5 & - & 110 & 61 & 8 \\
\hline $24 \mathrm{~B}$ & 15 & 8 & 0.2 & 442 & 258 & 7.4 \\
\hline $25 \mathrm{~L}$ & 31 & 0.5 & 12.3 & 396 & 186 & 8.8 \\
\hline $25 B$ & 25.4 & 2.4 & 2.9 & 425 & 189 & 8.2 \\
\hline $27 \mathrm{~L}$ & 21.5 & 0.5 & 5.1 & 96 & 48 & 9.2 \\
\hline $27 \mathrm{~B}$ & 13 & 7 & 7.7 & 229 & 56 & 7.7 \\
\hline $28 \mathrm{~L}$ & - & 0.5 & - & - & 65 & - \\
\hline $28 \mathrm{~B}$ & 15.8 & 21 & 0.2 & 120 & 63 & 7.4 \\
\hline
\end{tabular}

-, environmental variables could not be measured. 
The ordination from the DCA enabled the identification of associations between the sites in the ecological space (Fig. 5). In this ordination, the same assemblages that were identified by the Q-mode cluster could be recognized as well. Site $3 \mathrm{~B}$ is found in the negative side of axis 1 of the DCA, forming assemblage 5 , and is associated in the CCA with greater water depth values. The remaining sites nested on the negative side of axis 1 correspond to those sites that constitute assemblages 3 and 4, associated with shallow water bodies in the CCA. On the positive side of axis 1 of the DCA, all sites from assemblage 1 are plotted, almost overlapping each other, with the CCA showing their association with low values of conductivity and total alkalinity. Finally, site $16 \mathrm{~L}$ is also associated with these variables, and it is plotted in one of the DCA's borders.

\section{DISCUSSION}

Out of the 40 testate amoeba taxa observed in a previous study in the same water bodies of central Mexico, 25 (12 species plus 13 varieties) were recorded for the first time for the country (Sigala et al., 2016). Ecological preferences in tropical latitudes remain unknown for most of these species, however, so the results of our statistical analyses were used to infer details about their ecology in comparison with those known from temperate environments.

Despite the recent increase in studies of testate amoebae, their taxonomy remains elusive, with an obvious tendency for literature to keep identification at the species level, whereas other articles defend the use of varieties and "ecophenotypes" (Asioli et al., 1996). To avoid mistakes

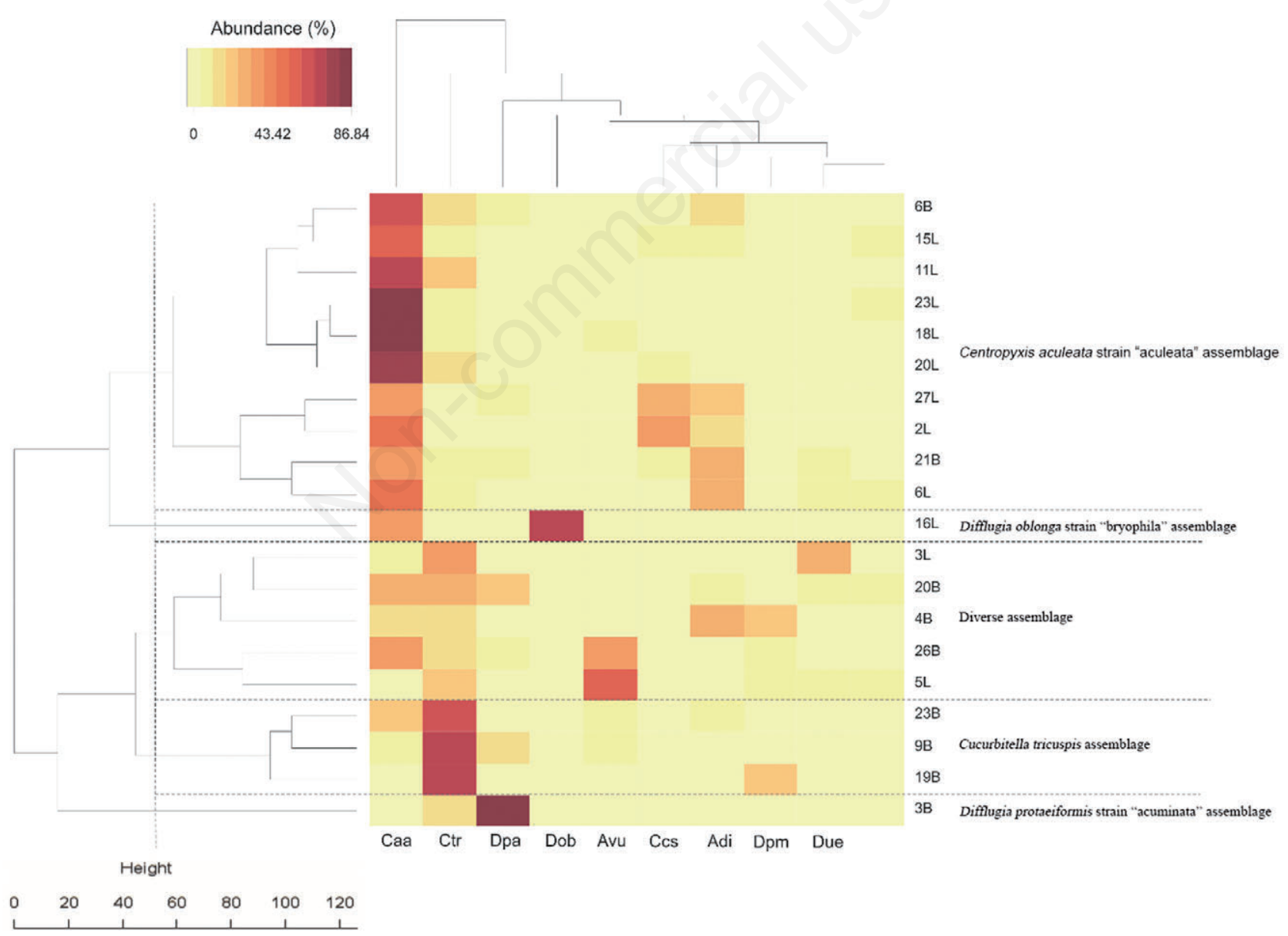

Fig. 4. The Q- and R-mode cluster analyses represented as a heat-map. The box colors indicate the relative abundance of species, where darker colors correspond to higher abundances and lighter ones with lower abundances. Five clusters were identified with the chosen Euclidean distance (75). Only statistically significant species and samples with $>50$ individuals were included, thus showing only the nine significant species. Codes for the species are given in Tab. 1, and those for lakes in Tab. 2. 
carried over due to the use of different taxonomic opinions, the comparisons we make here with published work consider only articles in which the species or variety name matches exactly with those we have reported in this study (excluding possible cases of synonymy).

\section{Relationships between environmental variables and species}

Although the testate amoeba communities we found in the central Mexican water bodies were comparable to those reported for temperate lakes, there exceptional species whose response to certain environmental variables differed.

\section{Centropyxis aculeata strain "aculeata" assemblage}

Since the water bodies we investigated are in the tropics, they are characterized by warm temperatures, and the warmest sites had the highest levels of dissolved oxygen. The lowest conductivity value was recorded in 27L and the highest in 6B (Tab. 3). Lake Aljojuca (site 2L) is a subsaline lake (Sigala et al., 2017) due to its high total dissolved solids values, whereas the others displayed lower values and are freshwater bodies. Values of $\mathrm{pH}$ were high for most of our 29 sites, with $27 \mathrm{~L}$ being the most basic. Most of the water bodies from which belong the sites in this group are eutrophic and hypertrophic, with only two of them described as mesotrophic (2B and 27L) according to Sigala et al. (2017). Therefore, the samples in this cluster share a suite of defining features: namely, warm temperatures, basic $\mathrm{pH}$, high trophic levels, and the abundance of Centropyxis aculeata strain "aculeata".

Centropyxis aculeata strain "aculeata" has been reported from temperate latitudes as an opportunistic species and an indicator of hostile environmental conditions, such as high salinity and conductivity levels (Roe and Patterson, 2014), high contamination by heavy

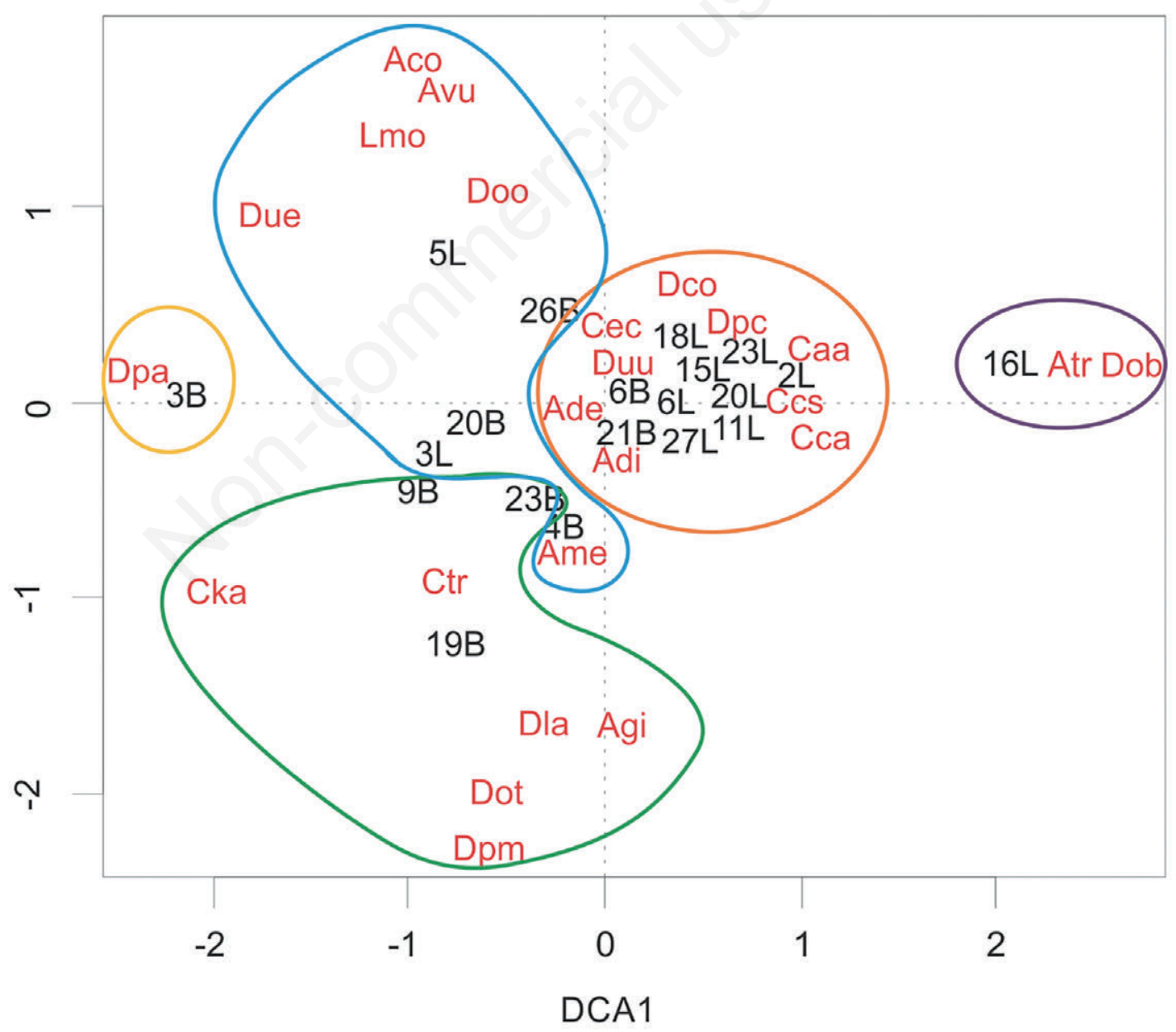

Fig. 5. Detrended correspondence analysis (DCA). The resulting ordinance is shown, with colored lines grouping the sites that constitute the five identified assemblages based on the Q-mode cluster: assemblage 1, orange; assemblage 2, purple; assemblage 3, blue; assemblage 4, green; assemblage 5, yellow. 
metals (Roe et al., 2010) and cooling events (Boudreau et al., 2005). In tropical water bodies, the highest abundance of this species is associated with cold periods (winter season) and a relatively low humidity (Farooqui et al., 2012). Centropyxis aculeate strain "aculeate" has been recorded in cenotes from the Yucatán peninsula at salinity levels of $1.5 \mathrm{psu}$, which makes it an euryhaline species (van Hengstum et al., 2008); this species was also found to occur at lower abundances in more saline waters, giving way to the strain "discoides", which is characterized by the absence of spines. To explain this change, the authors suggested the spineless varieties have an ecological advantage in oligohaline environments, while recognizing that in limnetic environments other stress factors may function to control the presence of spines on testate amoebae, such as $\mathrm{pH}$.

Another two species that define a sub-cluster of this group (formed by sites $27 \mathrm{~L}, 2 \mathrm{~L}, 6 \mathrm{~L}$, and 21B) are Centropyxis constricta strain "spinosa" and Arcella discoides; they were also associated together in the CCA, showing similar ecological preferences, specifically to low conductivity levels. The same varieties of Centropyxis were reported by Roe and Patterson (2014), who identified a sub-cluster composed of the same varieties as in our study, but with $A$. vulgaris present instead of $A$. discoides, that was associated with high salinity and conductivity levels which they attributed to the use of road salt. However, in our study, only one site (2L) was subsaline (Sigala et al., 2017). In the rest of the water bodies in this group the presence of Centropyxis aculeata strain "aculeata" may result from their hostile or stressful conditions caused by warm temperatures, basic $\mathrm{pH}$, and/or high trophic levels. This is reflected in the low Shannon index values of these sites (average, 1.34), which suggest a generally low alpha diversity, likely arising from unfavorable environmental conditions.

\section{Difflugia oblonga strain "bryophila" assemblage}

The only lake sample in this assemblage (16L) had a low Shannon index value (0.7), which reflects high dominance of one species, and an unfavorable environment that could hinder testate amoebae growth. This sample belongs to a subsaline, mesotrophic lake, located in the western region of Mexico (Sigala et al., 2017), which had a temperature of $29.8^{\circ} \mathrm{C}$, dissolved oxygen of $8.6 \mathrm{mg} \mathrm{L}^{-1}$, a pH of 8.6 and a high conductivity of $1347 \mu \mathrm{S} \mathrm{cm}^{-1}$. This sample stood out due to the great abundance of Difflugia oblonga strain "bryophila", along with Centropyxis aculeata strain "aculeata". All species of Difflugia need mineral particles to build their tests. This is possibly a factor determining their presence in the littoral area of this lake (Dalby et al., 2000), since Santa María del Oro is fed by streams with intermittent runoffs active only during the rainy season, thus favoring high sedimentation rates in the littoral areas (Caballero et al., 2013). Nevertheless, little is known specifically about Difflugia oblonga strain "bryophila". Its presence has been reported in lakes in Finland (Kauppila et al., 2006; Kihlman and Kauppila, 2012) and Canada (Patterson and Kumar, 2000; Neville et al., 2010; Boudreau et al., 2005; Reinhardt et al., 2005; Roe et al., 2010) and in subtropical regions, where Escobar et al. (2008) recorded this species in Florida in association with high alkalinity and $\mathrm{pH}$ values of lakes there. More research is required, but our results suggest this species prefers warm water bodies with basic $\mathrm{pH}$ and high sedimentation rates, not unlike the opportunistic Centropyxis aculeata strain "aculeata", whose ecological preferences are better known and occurs in basic pH conditions (Roe and Patterson, 2006).

\section{Diverse assemblage}

The sites that constitute this assemblage had an average Shannon index value of 1.9 , which means their environments alternate between favorable and unfavorable conditions. The water bodies in this cluster are distributed along central and eastern central Mexico, with warm temperatures; dissolved oxygen ranged from 5.3 to $7.8 \mathrm{mg} \mathrm{L}^{-1}$, the $\mathrm{pH}$ was basic, with site $3 \mathrm{~L}$ having among the greatest value, and the conductivity was very variable (Tab. 3). However, based on the TDS data, all these water bodies are considered as freshwater and their trophic state ranges from mesotrophic to eutrophic (Sigala et al., 2017). Within the cluster, a first group of samples (3L, 20B, 4B) lacked clear dominance by any particular species; instead, their abundances were rather well balanced; yet in a second group (5L and 26B) A. vulgaris was most dominant. In Canadian lakes, this species has been described as an indicator of acidic $\mathrm{pH}$ (Kumar and Patterson, 2000; Patterson and Kumar, 2000) and high heavy metal concentrations, given their apparent affinity for silver and other metals used to build their tests (Patterson et al., 1996, Patterson et al., 2002). Nonetheless, studies of other lakes in Canada have shown that an increase in A. vulgaris abundance is correlated with basic $\mathrm{pH}$ levels (Neville et al., 2010) and high conductivity (Roe et al., 2010; Roe and Patterson, 2014). In a lake in India, A. vulgaris and A. discoides followed the same pattern as the centropyxids, appearing only during the winter months (Farooqui et al., 2012). In Mexico, these species are reportedly associated with primary production in cenotes (van Hengstum et al., 2008). Our CCA shows A. vulgaris was linked to low $\mathrm{pH}$ levels, although neither of the studied water bodies was particularly acidic, with the lowest $\mathrm{pH}$ recorded at Lake La Luna (8B). More geochemical studies of these water bodies' sediments are required to confirm whether the species occurrences are linked to high levels of certain heavy metals. 


\section{Cucurbitella tricuspis assemblage}

This assemblage of sites had the same average Shannon index value as did assemblage 1 (1.3), suggesting unfavorable environmental conditions as well. The three sites are all shallow water bodies with warm temperatures and a slightly basic $\mathrm{pH}$, with similar conductivity (Tab. 3). These are freshwater water bodies located in the central and western regions of the study area; Santa Rosa (19B) is a mesotrophic lake, and the other two are hypertrophic (Sigala et al., 2017). The testate amoeba species that distinguishes this group is Cucurbitella tricuspis, a known bioindicator of eutrophication in temperate lakes (Patterson et al., 2002; 2012; Reinhardt et al., 2005; Kihlman and Kauppila, 2012). It is considered a planktonic species, probably with high lipid contents that improve its buoyancy, and is usually associated with Spirogyra algae (Volik et al., 2016). Importantly, C. tricuspis may be carried between lakes by wind currents, which explains their presence in high numbers, even in contaminated lakes (Roe and Patterson, 2014). However, this species was recorded in Florida in a lake with low total phosphorous levels, suggesting that it responds differently under subtropical environments (Escobar et al., 2008). In our study, the trophic state of at least two sites from this cluster (9B and 23B) supports the presence of Cucurbitella tricuspis as a high trophic level bioindicator.

\section{Difflugia protaeiformis strain "acuminata" assemblage}

Shannon index value for this sample was low (0.6), as it was characterized by the dominance of Difflugia protaeiformis strain "acuminata". The CCA shows this variety's preference for greater water depths. The sample was collected from a freshwater mesotrophic lake (Sigala et al., 2017) at a 16.5-m depth (3B), where the dissolved oxygen readings were very low but the temperature was high (Tab. 3). Generally, the genus Difflugia is associated with high amounts of organic substrate that used as material for the construction of their tests (Patterson and Kumar, 2000). Varieties of D. protaeifromis are linked to substrates contaminated with metals and metalloids, in conditions of severe environmental stress (Patterson and Kumar, 2000; Nasser et al., 2016). Difflugia protaeiformis strain "acuminata" has been linked to low carbon concentrations and low oxygen environments (Kihlman and Kauppila, 2012), without any clear preference for any specific substrate particle size (Macumber et al., 2014), although some authors have reported its presence on boggy substrates characterized by the abundance of pennate diatoms (Reinhardt et al., 1998; Patterson and Kumar, 2000). Recently, it was suggested that $D$. protaeiformis could be an indicator of high conductivity levels (Roe and Patterson, 2014), but its investigation in tropical lakes has never been done before. This study confirms this variety as a possible bioindicator of low oxygen levels in tropical latitudes.

\section{Testate amoebae as bioindicators of environmental stress}

The sampled testate amoeba communities in central Mexico water bodies revealed that these environments are unfavorable or stressful for testate amoebae. More research regarding lacustrine sediments is needed to confirm the source(s) of such stress, which could be related to the proliferation of nearby human settlements, which exert a considerable impact by polluting and modifying the conditions of these waters. A geochemical study of these sediments could, for example, confirm high heavy metal concentrations that would likely explain the occurrence of particular species, such as Arcella vulgaris and Difflugia protaeiformis strain "acuminata", and further confirm both species as having similar ecological preferences in temperate and tropical environments.

Importantly, we must also consider the possibility that shifts in the regional climate regimes could be responsible for these stress conditions. At least in the case of Lake Pátzcuaro, there are records on how this lake's depth and area have changed considerably, becoming shallower and smaller over recent years (Gomez-Tagle et al., 2002).

\section{CONCLUSIONS}

Our results show that Cucurbitella tricuspis and Difflugia protaeiformis strain "acuminata" maintain the same ecological preferences in both tropical and temperate lake systems. Yet testate amoebae species largely recognized and characterized as indicators of high salinity and low pH levels - such as Centropyxis aculeata strain "aculeata" and Arcella vulgaris, respectively - may also indicate stressful conditions in tropical lakes, albeit driven by different environmental factors, perhaps trophic structure. In high $\mathrm{pH}$ environments, however, Difflugia oblonga strain "bryophila" may also function as an opportunistic species. Evidently, only through more empirical field studies in tropical regions can we hope to broaden our understanding of how these testate amoebae species are distributed in these latitudes. Such future work should consider critical environmental information, such as the vegetation of the littoral zones or the sediment type, size and geochemistry. The testate amoeba communities described in these Mexican water bodies reveal an important relationship between these organisms and environmental factors, which could be key sources of environmental stress, along with the water bodies' contamination from human settlements surrounding them. 


\section{ACKNOWLEDGMENTS}

This research was funded by several grants: Consejo Nacional de Ciencia y Tecnología (CONACyT) 167621, CONACyT 190519, Programa de Apoyo a Proyectos de Investigación e Innovación Tecnológica - Universidad Nacional Autónoma de México (PAPIIT-UNAM) IA101912, and National Science Centre (NCN) 2014/13/B/ST10/02534. Itzel Sigala thanks the Posgrado de Ciencias Biológicas, UNAM and CONACyT (CVU 294479) for their financial support. Special thanks go to Alejandro Angeles, Mariela Esquivel, Jacqueline Jasso, Antonio Guerra and Manuel Valle for their help in the laboratory. We also thank Laura Luna González from the Digital Mapping Laboratory, Instituto de Geología, UNAM, for the map elaboration; Boon Graphics Producciones for editing the images; and Rosaura Mayén and Margarita Reyes for lending us the specialized bibliography.

\section{REFERENCES}

APHA, 1995. Standard methods for the examination of water and wastewater. American Public Health Association/American Water Works Association/Water Environment Federation, Washington DC: $1015 \mathrm{pp}$.

APHA, 1998. Standard methods for the examination of water and wastewater. American Public Health Association/American Water Works Association/Water Environment Federation, Washington DC: 1193 pp.

APHA, 2005. Standard methods for the examination of water and wastewater. American Public Health Association/American Water Works Association/Water Environment Federation, Washington DC: 1360 pp.

Armienta MA, Vilaclara G, De la Cruz-Reyna S, Ramos S, Ceniceros N, Cruz O, Aguayo A, Arcega-Cabrera F, 2008. Water chemistry of lakes related to active and inactive Mexican volcanoes. J. Volcanol. Geoth. Res. 178:249-258.

Armynot du Châtelet, E, Bernard N, Delaine M, Potdevin JL, Gilbert D, 2015. The mineral composition of the tests of 'testate amoebae' (Amoebozoa, Arcellinida): The relative importance of grain availability and grain selection. Rev. Micropaleontol. 58:141-154.

Asioli A, Medioli FS, Patterson RT, 1996. Thecamoebians as a tool for reconstruction of paleoenvironments in some Italian lakes in the foothills of southern Alps (Orta, Varese and Candia). J. Foramin. Res. 26:248-263.

Boudreau REA, Galloway JM, Patterson RT, Kumar A, Michel FA, 2005. A paleolimnological record of Holocene climate and environmental change in the Temagami region, northeastern Ontario. J. Paleolimnol. 33: 445-461.

Caballero M, Rodríguez A, Vilaclara G, Ortega B, Roy P, Lozano S, 2013. Hydrochemistry, ostracods and diatoms in a deep, tropical, crater lake in Western Mexico. J. Limnol. 72:512-523.

Caballero M, Vázquez G, Ortega B, Favila ME, Lozano-García S, 2015. Responses to a warming trend and "El Niño" events in a tropical lake in western Mexico. Aquat Sci. 78:591-604.
Dalby AP, Kumar A, Moore JM, Patterson RT, 2000. Preliminary survey of Arcellaceans (Thecamoebians) as limnological indicators in tropical Lake Sentani, Irian Jaya, Indonesia. J. Foramin. Res. 30:135-142.

Davies SJ, Metcalfe SE, Caballero ME, Juggins S, 2002. Developing diatom-based transfer functions for Central Mexican lakes. Hydrobiologia 467:199-213.

de Oliveira MT, Hardoim EL, 2010. Study of testacean assemblages (Protozoa: Rhizopoda) in touristic waterfall regions of Chapada dos Guimarães National Park, Mato Grosso State, Brazil. Acta Sci. Biol. Sci. 32:387-395.

Escobar J, Brenner M, Whitmore T J, Kenney W F, Curtis J H, 2008. Ecology of testate amoebae (thecamoebians) in subtropical Florida lakes. J. Paleolimnol. 40:715-731.

Farooqui A, Kumar A, Swindles GT, 2012. Thecamoebian communities as proxies of seasonality in Lake Sadatal in the Ganga-Yamuna Plains of North India. Palaeontol. Electronica 15:1-19.

Fernández LD, Zapata J, Meisterfeld R, Baessolo L, 2012. First records and community pattern of Arcellinida Inhabiting a pristine and remote Island from Southeastern Pacific, Chile. Acta Protozool. 51:139-154.

Ferrari L, Orozco-Esquivel T, Manea V, Manea M, 2012. The dynamic history of the Trans-Mexican Volcanic Belt and the Mexico subduction zone. Tectonophysics 522:122-149.

Gomez-Tagle A, Bernal-Brooks FW, Alcocer J, 2002. Sensitivity of Mexican water bodies to regional climatic change: three study alternatives applied to remote sensed data of Lake Patzcuaro. Hydrobiologia 467:169-176.

ICZN (International Commission on Zoological Nomenclature), 1999. International Code of Zoological Nomenclature, London: 306 pp.

Kauppila T, Kihlman S, Mäkinen J. 2006. Distribution of arcellaceans (Testate amoebae) in the sediments of a mine water impacted Bay of Lake Retunen, Finland. Water Air Soil Poll. 172:337-358.

Kihlman S, Kauppila T, 2012. Effects of mining on testate amoebae in a Finnish lake. J. Paleolimnol. 47: 1-15.

Kumar A, Dalby AP, 1998. Identification key for Holocene lacustrine arcellacean (thecamoebian) taxa. Palaeontol. Electronica 1:1-39.

Kumar A, Patterson RT, 2000. Arcellaceans (Thecamoebians): New tools for monitoring long and short term changes in lake bottom acidity. Environ. Geol. 39:689-697.

Lee JJ, Leedale G, Bradbury P, 2000. An illustrated guide to the protozoa. Society of Protozoologists: $1432 \mathrm{pp}$.

Macumber AL, Patterson RT, Roe HM, Reinhardt EG, Neville LA, Swindles GT, 2014. Autoecological approaches to resolve subjective taxonomic divisions within Arcellacea. Protist 165:305-316.

Maia-Barbosa PM, Peixoto RS, Guimarães AS, 2008. Zooplankton in littoral waters of a tropical lake: a revisited biodiversity. Braz. J. Biol. 68:1069-1078.

Mattheeussen R, Ledeganck P, Vincke S, van de Vijver B, Nijs I, Beyens L, 2005. Habitat selection of aquatic testate amoebae communities on Qeqertarsuaq (Disko Island), West Greenland. Acta Protozool. 44:253-263.

Meeks J, 1974. Chlorophylls, p. 161-175. In: P. Stewart (ed.), Algal physiology and biochemistry. University of California Press. 
Meyer C, Gilbert D, Gillet F, Moskura M, Franchi M, Bernard $\mathrm{N}, 2012$. Using "bryophytes and their associated testate amoeba" microsystems as indicators of atmospheric pollution. Ecol. Indic. 13:144-151.

Nasser NA, Patterson RT, Roe HM, Galloway JM, Falck H, Palmer MJ, Spence C, Sanei H, Macumber AL, Neville LA, 2016. Lacustrine Arcellinina (Testate amoebae) as bioindicators of arsenic contamination. Environ. Microbiol. 72: 30-149.

Neville LA, McCarthy FMG, MacKinnon MD, 2010. Seasonal environmental and chemical impact on thecamoebian community composition in an oil sands reclamation wetland in northern Alberta. Palaeontol. Electronica 13:1-14.

OECD (Organization for Economic Co-operation and Development), 1982. Eutrophication of waters. Monitoring, assessment and control. Organization for Economic Cooperation and Development, Paris: $154 \mathrm{pp}$.

Ogden CG, Hedley H, 1980. An atlas of freshwater testate amoebae. Oxford University Press, Oxford: 222 pp.

Patterson RT, Fishbein A, 1989. Re-examination of the statistical methods used to determine the number of point counts needed for micropaleontological quantitative research. J. Paleontol. 63: 45-248.

Patterson RT, Kumar A, 2000. Assessment of arcellacean (Thecamoebian) assemblages, species, and strains as contaminant indicators in James Lake, Northeastern Ontario, Canada. J. Foramin. Res. 30:310-320.

Patterson RT, Kumar A, 2002. Use of Arcellacea (Thecamoebians) to gauge levels of contamination and remediation in industrially polluted lakes, p. 257-278. In: R.E. Martin (ed.) Environmental micropaleontology. Kluwer, Dordrecht.

Patterson RT, Barker T, Burbidge SM, 1996. Arcellaceans (Thecamoebians) as proxies of arsenic and mercury contamination in northeastern Ontario Lakes. J. Foramin. Res. 26:172-183.

Patterson RT, Dalby A, Kumar A, Henderson LA, Boudreau REA, 2002. Arcellaceans (thecamoebians) as indicators of land-use change: settlement history of the Swan Lake area, Ontario as a case study. J. Paleolimnol. 28:297-316.

Patterson RT, Roe HM, Swindles GT, 2012. Development of an Arcellacea (testate lobose amoebae) based transfer function for sedimentary phosphorus in lakes. Palaeogeogr. Palaeoclimatol. Palaeoecol. 348-349:32-44.

Payne RJ, 2013. Seven reasons why protists make useful bioindicators. Acta Protozool. 52:105-113.

Payne RJ, Mitchell EAD, 2009. How many is enough? Determining optimal count totals for ecological and palaeoecological studies of testate amoebae. J. Paleolimnol. 42:483-495.

Qin Y, Mitchell EAD, Lamentowicz M, Payne RJ, Lara E, Gu Y, Huang X, Wang H, 2013. Ecology of testate amoebae in peatlands of central China and development of a transfer function for paleohydrological reconstruction. J. Paleolimnol. 50:319-330.

Reinhardt E, Dalby AP, Kumar A, Patterson RT, 1998. Arcellaceans as pollution indicators in mine tailing contaminated lakes near Cobalt, Ontario, Canada. Micropaleontology 44:131-148.

Reinhardt EG, Little M, Donato S, Findlay D, Krueger A, Clark C, Boyce J, 2005. Arcellacean (thecamoebian) evidence of land-use change and eutrophication in Frenchman's Bay, Pickering, Ontario. Environ. Geol. 47:729-739.

Roe HM, Patterson RT, 2006. Distribution of thecamoebians (Testate amoebae) is small lakes and ponds, Barbados, West Indies. J. Foramin. Res. 36:116-134.

Roe HM, Patterson, RT, 2014. Arcellacea (Testate Amoebae) as bio-indicators of road salt contamination in lakes. Microb. Ecol. 68:299-313.

Roe HM, Patterson RT, Swindles GT, 2010. Controls on the contemporary distribution of lake thecamoebians (testate amoebae) within the Greater Toronto Area and their potential as water quality indicators. J. Paleolimnol. 43: 55-975.

Sigala I, Lozano-García S, Escobar J, Pérez L, Gallegos-Neyra E, 2016. Testate amoebae (Amebozoa: Arcellinida) in tropical lakes of Central Mexico. Rev. Biol. Trop. 64:377-397.

Sigala I, Caballero M, Correa-Metrio A, Lozano-García S, Vázquez G, Pérez-Alvarado L, Zawisza E, 2017. Basic limnology of 30 continental waterbodies of the Transmexican Volcanic Belt across climatic and environmental gradients. Bol. Soc. Geol. Mex. 69:313-370.

Swindles GT, Amesbury MJ, Turner TE, Carrivick JL, Woulds C, Raby C, Mullan D, Roland TP, Galloway JM, Parry L, Kokfelt U, Garneau M, Charman DJ, Holden J, 2015. Evaluating the use of testate amoebae for palaeohydrological reconstruction in permafrost peatlands. Palaeogeogr. Palaeoclimatol. Palaeoecol. 424:111-122.

van Hengstum PJ, Reinhardt EG, Beddows PA, Huang RJ, Gabriel JJ, 2008. Thecamoebians (Testate amoebae) and foraminifera from three anchialine cenotes in Mexico: low salinity (1.5- $4.5 \mathrm{psu}$ ) faunal transitions. J. Foramin. Res. 38:305-317.

Volik O, McCarthy FMG, Riddick NL, 2016. Insights from pollen, non-pollen palynomorphs and testate amoebae into the evolution of Lake Simcoe. J. Paleolimnol. 56:137-152. 